International Research Journal of Management, IT \& Social Sciences
Available online at https://sloap.org/journals/index.php/irjmis/
Vol. 7 No. 6, November 2020, pages: 33-41
$\begin{aligned} & \text { ISSN: 2395-7492 } \\ & \text { https://doi.org/10.21744/irjmis.v7n6.1006 }\end{aligned}$

\title{
Debiasing Halo Effect: Auditor Reputation and the Role of Auditing Learning on Financial Statements User Trust
}

\author{
Radian Sri Rama ${ }^{a}$ \\ Sutrisno $\mathbf{T}^{\mathrm{b}}$ \\ Erwin Saraswati $^{c}$ \\ Aulia Fuad Rahman ${ }^{\text {d }}$
}

Article history:

Submitted: 09 July 2020

Revised: 18 August 2020

Accepted: 27 September 2020

\section{Keywords:}

auditing learning;

auditor reputation;

financial statements;

halo effect;

trust;

\section{Corresponding author:}

Radian Sri Rama,

Accounting Department, Brawijaya University, Indonesia.

Email address: radiansrirama19@gmail.com

\begin{abstract}
The purpose of this study was to examine the effect of auditor reputation (big four and non-big four) and auditing learning (with audit learning and without audit learning) on the trust of users of financial statements. Testing the influence of the auditor's reputation and learning will show a halo effect on users of financial statements. The research method used was an experiment. Participants were 102 students. Data analysis was performed with the two-way Anova test. The results showed a halo effect so that the auditor's reputation and audit learning affected the users of financial statements.
\end{abstract}

International research journal of management, IT and social sciences (C) 2020. This is an open access article under the CC BY-NC-ND license (https://creativecommons.org/licenses/by-nc-nd/4.0/).

Accounting Department, Brawijaya University, Indonesia

b Accounting Department, Brawijaya University, Indonesia

Accounting Department, Brawijaya University, Indonesia

d Accounting Department, Brawijaya University, Indonesia 


\section{Introduction}

User trust in financial statements is obtained based on confidence in quality audits (Rodgers et al., 2019). The trust of users of financial statements increases if an audit is carried out by a reputable auditor. Users of these financial statements include investors (Mayhew, 2001; Bigus, 2015) and creditors (Kanagaretnam et al., 2009; Cano-Rodríguez et al., 2016). The use of financial statements depends more on the auditor's reputation to value companies with high information uncertainty (Billingsley \& Schneller, 2009). The trust of users of financial statements increases because users of financial statements believe the auditor's reputation will prevent managers from making earnings arrangements (Magnis \& Iatridis, 2017) and believe that the auditor's reputation will prevent information asymmetry (Godbey \& Mahar, 2005).

Some of the research results above show that the auditor's reputation can increase the trust of users of financial statements. However, in some cases, fraud has occurred in companies that use the services of reputable auditors, for example, the Enron case. Although it is the responsibility of many parties, the responsibility of the independent auditor, Arthur Andersen, is very large (Krishnamurthy et al., 2006). Examples of cases of fraud involving reputable auditors show that there is a gap between the results of research on trust in reputable auditors and fraud involving reputable auditors (Rodgers et al., 2019). The gap between the expectations (perceptions) of users of financial statements on the role and reputation of auditors with the reality that occurs is called the expectation gap (Cohen et al., 2017).

This study seeks to explain and test cognitive biases that make gaps in expectations emerge with existing theories in the field of cognitive psychology namely the halo effect. The hallmark of the halo effect is the existence of a reputation, good impression, good image, and good name which is the impression of an object. A stronger impression will be a cognitive bias (Leuthesser et al., 1995). In phenomena or cases of fraud that have occurred, reputable auditors' reputations that fall into the big five or big four categories have convinced the public and made an impression (Craswell et al., 1995; Putra \& Dwirandra, 2019). This study aims to provide empirical evidence and test: (1) Reputation auditor opinion shapers cause the appearance of a halo effect that affects the confidence of users of financial statements, (2) Learning auditing effect on the confidence of users of financial statements, (3) Interaction auditor reputation and learning auditing can affect the trust of users of financial statements.

\section{Literature review and hypothesis development}

\section{Halo effect}

The halo effect is one of the cognitive biases that occur when the overall impression of someone or something is obtained from generalizing one of its characteristics (Thorndike, 1920; Nisbett \& Wilson, 1977). The halo effect as a cognitive bias refers to the observer's impression of a person, company, brand, or product that affects the observer's feelings and thoughts about the character or nature of the entity. The source of this halo effect according to the theory of belief adjustment is an illusory correlation, that is, two variables that are considered as related when in reality they are not related (Hogarth \& Einhorn, 1992). A construct like a halo effect is not something real but only a psychological concept. Psychological attributes are generally seen as a single construct consisting of several aspects of behavior that are derived from the underlying theoretical concepts (Azwar, 1999). The variable of user confidence in the financial statements is the variable used to measure the halo effect due to the auditor's reputation.

\section{Trust}

Ehavior \& Pavlou (2002), define trust as the assessment of one's relationship with others who will carry out certain transactions following expectations in an environment that is full of uncertainty. Trust occurs when a person believes in the reliability and integrity of a trusted person (Morgan \& Hunt, 1994). According to Doney \& Cannon (1997), that the initial creation of partnership relationships is based on trust. The same thing also stated by McKnight et al. (2002), that trust is built before certain parties know each other through interactions or transactions.

\section{Auditor's reputation}

Reputation is a combination of activities over the life span of an entity, historical ideas, and requires consistency in the actions of an entity for a long time to form (Herbig et al., 1994). A reputation is a multidimensional form and a public accounting firm will have a reputation that reflects the quality of work in the various services it offers, such as auditing, 
accounting, taxation, management consulting, computer system advice, personnel selection, and others. In this study, what is meant as a reputable auditor is a Public Accounting Firm or a large audit firm? Currently, the world's largest audit firm is The Big Four, Deloitte, PriceWaterhouse Coopers, Ernest \& Young, and KPMG

\section{Auditing learning}

Gagne (1984), revealed that learning is a complex activity. After learning people have skills, knowledge, attitudes, and values. The achievement of learning outcomes (learning outcomes) is an acquired behavior that changes learners after experiencing learning activities. For the scope of the audit, the mastery of knowledge to be achieved is to master the theoretical concepts in-depth about planning, procedures, and reporting audits. Monroe \& Woodliff (1993), found in their research that learning accounting and auditing would reduce excessive expectations of the role of auditors in society.

\section{Relations auditor reputation and trust financial statement users}

The relationship of trust between organizational management and stakeholders can be reflected in the trust in financial statements (Baldvinsdottir et al., 2011). The trust characteristics that underlie the relationship between stakeholders and organizational management indicate that trust vulnerability can be reduced if there are independent parties that measure and control risk, for example, auditors (Frooman, 1999). Reputable auditors' reputation which is included in the big five or big four categories has convinced the public and made an impression (Craswell et al., 1995; Barton, 2005; Tedeschi, 2013). A stronger impression will be a cognitive bias (Leuthesser et al., 1995). Based on the arguments and the results of previous research, then the hypothesis can be formulated as follows:

H1: There are differences in user confidence in financial statements when the financial statements are audited by auditors with different reputations (big four and non-big four audit firms).

\section{Relationship of auditing learning and financial statements user trust}

Hogarth \& Einhorn (1992), in belief adjustment theory, predict that when individuals get high information input, the revision of their beliefs will be high. The learning function is to provide revisions to the initial information. Research shows that users of financial statements auditing the learning gain can understand the duties and responsibilities of the auditor to the audited financial statements (Monroe \& Woodliff, 1993). Based on the description above formulation of hypotheses as follows:

H2: There is a difference in the user's trust in the financial statements when the user gets different auditing learning (gets and does not get auditing learning).

\section{Relationship of auditor reputation, auditing learning and financial statements user trust}

Learning is a complex process (Gagne, 1984), so learning will have an impact on changes in the behavior of learners that are different depending on the process and learning material provided (Rifa'i \& Anni, 2012). Auditing learning can reduce the bias of the halo effect because of the auditor's reputation, but can be the opposite, namely strengthening the influence of the auditor's reputation so that it is increasingly biased in assessing misstatements that may exist in the financial statements. Based on the arguments and the results of previous research, then the hypothesis can be formulated as follows:

H3: There is an interaction of auditor reputation and auditing learning on the trust of users of financial statements.

\section{Materials and Methods}

The study was conducted with a genuinely experimental, because it has significant control over the variables studied and the confounding variables, and there is a control group (Shadish et al., 2002). The subjects of the experiment were students of the Faculty of Economics and Business, majoring in Accounting with criteria that had taken the Auditing course, while the non-A majors majored with criteria of students who had or were taking the Introduction to Accounting course.

Rama, R. S. ., T, S., Saraswati, E. . ., \& Rahman, A. F. . (2020). Debiasing halo effect: auditor reputation and the role of auditing learning on financial statements user trust. International Research Journal of Management, 
Operational Definitions and Measurement variables: (1) Auditor's reputation, this variable is categorical (nominal), that is, a big four Public Accounting Firm is coded 1 and a non-big four KAP is coded 2. (2) Auditing Learning Financial Report Users, this variable is categorical variables (nominal), classes with auditing learning are coded 1 and classes without auditing learning are coded 2. (3) Financial Statements User Trust, variables of financial statement users are measured using a questionnaire with a Likert scale of 1-7 namely: 1. Strongly Disagree, 2 . Disagree, 3. Somewhat Disagree, 4. Neutral, 5. Somewhat Agree, 6. Agree, 7. Strongly Agree.

The study used a 2 × 2 factorial design consisting of four treatment cells. Random assignment is done by distributing subjects in the group of audited financial statements big four and the group of financial statements audited non-big four is done randomly so that the condition of the subject in each group is equivalent (Nahartyo \& Utami, 2014). Randomization design is completely randomized design, each subject has the same opportunity to be an experimental group and a control group. The design of this experimental research is shown in table 1.

Table 1

Factorial Design Experiments

\begin{tabular}{lll}
\hline Auditor & Getting & Not Getting \\
& Auditing Learning & Auditing Learning \\
\hline Big Four & cell 1 & cell 2 \\
Non-Big Four & cell 3 & cell 4 \\
\hline
\end{tabular}

Source: researcher data

Manipulation is done by dividing participants into two classes: classes with auditing learning and classes without auditing learning. In each class, two types of audited financial statements are distributed, with audit opinions of financial statements from Public Accounting Firm big four and non-big four. Analisis the data using the Manova test.

\section{Results and Discussions}

\section{Experiments and research subjects}

The experiment was conducted in the form of financial statement review activities on November 28, 2019, at Brawijaya University, Malang City. Participants invited in this experiment were 111 undergraduate students of the Faculty of Economics and Business, Accounting Department, and Management Department, who met the criteria, namely for participants from the accounting department who had /were taking auditing courses and for participants majoring in management had taken courses introductory lecture in accounting. The data that can be processed is data from 102 participants. The distribution of participants in the four treatment cells is shown in Table 2.

Table 2

Distribution of participants in experiments

\begin{tabular}{lll}
\hline Auditor & Getting Auditing Learning & No Auditing Learning \\
\hline Big Four & 25 people & 30 people \\
Non-Big Four & 26 people & 21 people \\
\hline
\end{tabular}

Source: researcher data

Table 2 shows that the number of participants in the treatment cells did not have a significant difference. The distribution of participants in each cell uses randomization so that each participant has an equal opportunity to accept manipulation. Randomization can also guarantee that the results of experiments have high internal validity. The demographic characteristics of the participants are also presented in the form of descriptive statistics which are described in Table 3. 
Table 3

Participant demographic descriptive statistics

\begin{tabular}{|c|c|c|c|c|c|c|c|c|}
\hline Information & & $\mathrm{N}$ & Range & Min & Max & $\begin{array}{l}\text { Score- } \\
\text { flat }\end{array}$ & $\begin{array}{l}\text { Standard } \\
\text { Deviation } \\
\text { Baku }\end{array}$ & Variant \\
\hline Type & Male & 54 & 1 & 1 & 2 & 1.47 & 0.50 & 0.25 \\
\hline Sex & Female & 48 & & & & & & \\
\hline \multirow[t]{4}{*}{ Age } & 19 years old & 9 & 3 & 19 & 22 & 20.25 & 0.69 & 0.48 \\
\hline & 20 years & 64 & & & & & & \\
\hline & 21 years old & 23 & & & & & & \\
\hline & 22 years old & 6 & & & & & & \\
\hline \multirow[t]{2}{*}{ Education } & Accounting & 55 & 1 & 1 & 2 & 1.46 & 0.50 & 0.25 \\
\hline & Management & 47 & & & & & & \\
\hline
\end{tabular}

Source: researcher data

Table 3 shows that male and female participants are almost the same (male 52.9 percent, female 47.1 percent). The minimum age of participants is 19 years and the maximum age is 22 years. The majority of participants were 20 years old (62.7 percent). Educational background from 55 accounting majors and 47 from management majors.

\section{Hypothesis 1 (H1) testing}

Hypothesis 1 testing is conducted to prove that there are differences in user confidence in the financial statements audited by the big four and non-big four. Table 4 shows the results of $\mathrm{H} 1$ testing have a significant value of less than 0.05 (P-Value $(0,000) \leq 0.05)$, meaning that with a real level of $5 \%$ the data provides sufficient evidence that the amount of trust is influenced by the reputation variable. This result supports hypothesis 1 .

Table 4

Tests of Between-Subjects Effects

Dependent Variable: TRUST

\begin{tabular}{llllll}
\hline Source & $\begin{array}{l}\text { Type III Sum of } \\
\text { Squares }\end{array}$ & df & Mean Square & F & Sig. \\
\hline Corrected Model & 90,983 a & 3 & 30,328 & 296,716 & .000 \\
Intercept & .503 & 1 & .503 & 4,924 & .029 \\
Auditor Type & 5,369 & 1 & 5,369 & 52,532 & .000 \\
Education & 80,560 & 1 & 80,560 & 788,166 & .000 \\
Type of Auditor $*$ & .003 & 1 & .003 & .31 & .861 \\
Education & 10,017 & 98 & 102 & & \\
Error & 101,000 & 102 & & & \\
Total & 101,000 & 101 & & & \\
Corrected Total & & & & & \\
\hline
\end{tabular}

a. R Squared = .901 (Adjusted R Squared $=.898$ )

Hypothesis 2 (H2) Testing

Hypothesis 2 testing is conducted to prove that there are differences in trust in users of financial statements with auditing learning and without auditing learning. Table 4 shows the results of $\mathrm{H} 2$ testing have a significant value of less than $0.05(P$-Value $(0,000)>0.05)$, meaning that with a real level of $5 \%$ the data provides sufficient evidence that the size of the trust variable is influenced by the auditing learning variable. This result 1 supports hypothesis 2 .

Rama, R. S. ., T, S., Saraswati, E. .., \& Rahman, A. F. . (2020). Debiasing halo effect: auditor reputation and the role of auditing learning on financial statements user trust. International Research Journal of Management, IT and Social Sciences, 7(6), 33-41. https://doi.org/10.21744/irjmis.v7n6.1006 


\section{Hypothesis 3 (H3) testing}

Hypothesis 3 testing is conducted to prove that there is an interaction between auditor reputation and auditing learning on the trust of users of financial statements. Table 4. shows the results of $\mathrm{H} 3$ testing has a value of more than $0.05(P$ Value $(0.861)>0.05)$, meaning that with a real level of $5 \%$ the data provides sufficient evidence that the size of the trust variable is not influenced by the interaction between the auditor's reputation variable and the learning variable auditing. This result does not support hypothesis 3 (H3).

\section{Discussion \\ Relationship of auditor reputation and financial statements user trust}

H1 test results support research that the trust of users of financial statements is increasing, if audits are carried out by reputable auditors (Weber et al., 2008; Brown \& Dang, 2011), besides that investor confidence as one of the users of financial statements will be higher in companies that are audited by reputable auditors (Lennox, 1999; Mayhew, 2001; Hillison \& Pacini, 2004; Godbey \& Mahar, 2005; Ackert et al., 2007; Krishnamurthy et al., 2006). These results also support research which states that the reputation of reputable auditors belonging to the big five or big four categories has convinced the public, made an impression and caused a halo effect (Craswell et al., 1995; Barton, 2005; Tedeschi, 2013). A stronger impression will be a cognitive bias (Leuthesser et al., 1995; Timothy Coombs \& Holladay, 2006; Park et al., 2011; Cho \& Kim, 2012).

\section{Relationship of auditing learning and financial statements user trust}

H2 test results support Hogarth \& Einhorn (1992) in the theory of belief adjustment, which predicts that when an individual gets high input information, the revision of his belief will be high. Conversely, when additional information is low, the possibility of revising confidence will be low too. The learning function is to provide revisions to the initial information. The results of this study are in line with learning theory which suggests that learning is a process of adaptive behavior that is progressive (Skinner, 1958). Learning is a set of cognitive processes that change the nature of the environmental stimulus, passing information processing, into new capabilities (McGeoch, 1933; Gagne, 1984). Research shows that financial statement users who obtain auditing learning can understand the duties and responsibilities of auditors on audited financial statements (Monroe \& Woodliff, 1993; Gramling et al., 1996; Pierce \& Kilcommins, 1997). The results of this study prove that auditing learning on financial statement users affects the trust of financial statement users.

\section{Relationship of auditor reputation, auditing learning and financial statements user trust}

Hypothesis 3 states that there is an interaction of auditor reputation and auditing learning on the trust of users of financial statements. The results of the testing do not support hypothesis 3. Regarding the interpretation of results like this, Christensen (2004) notes, if the main effect (main effect) of the independent variable (auditor reputation and auditing learning) obtained significant results, while the interaction effect between the independent variables involved is not significant, it can be concluded that the independent variables (auditor's reputation and auditing learning) affect the dependent variable (trust). The interaction shows the pattern of each factor tested differently (Field, 2009). Testing the main effects of this research, namely testing $\mathrm{H} 1$ and $\mathrm{H} 2$ the results are significant, so it can be concluded that although the interaction effect test is not significant, the auditor's reputation variable and auditing learning variables are proven to affect the user's confidence variable.

\section{Conclusion}

This study aims to provide empirical evidence that the auditor's reputation causes a halo effect that affects the trust and valuation of financial statement misstatements, as well as the role of auditing learning on trust and valuation of financial statement misstatements. The results of testing the main influence hypothesis prove that: (1) the auditor's reputation influences the trust of users of financial statements. The results of this study support the halo effect which is seen as an explanatory phenomenon. This finding also reinforces the impression theory as a supporting theory in this study, (2) auditing learning on financial statement users affects the trust of financial statement users. These results support 
the theory of belief adjustment and show that the beliefs (beliefs) of users of financial statements will be corrected with information in the form of auditing learning materials.

\section{Conflict of interest statement}

The authors declared that they have no competing interests.

Statement of authorship

The authors have a responsibility for the conception and design of the study. The authors have approved the final article.

Acknowledgments

We are grateful to two anonymous reviewers for their valuable comments on the earlier version of this paper.

Rama, R. S. ., T, S., Saraswati, E. . ., \& Rahman, A. F. . (2020). Debiasing halo effect: auditor reputation and the role of auditing learning on financial statements user trust. International Research Journal of Management, IT and Social Sciences, 7(6), 33-41. https://doi.org/10.21744/irjmis.v7n6.1006 


\section{References}

Ackert, L. F., Church, B. K., \& Schneider, A. (2007). Auditor Reputation and Individuals' Investment Decisions.

Azwar, S. (1999). Penyusunan skala psikologi. Pustaka pelajar.

Baldvinsdottir, G., Hagberg, A., Johansson, I. L., Jonäll, K., \& Marton, J. (2011). Accounting research and trust: a literature review. Qualitative Research in Accounting \& Management.

Barton, J. (2005). Who cares about auditor reputation?. Contemporary accounting research, 22(3), 549-586.

Bigus, J. (2015). Auditor reputation under different negligence regimes. Abacus, 51(3), 356-378.

Billingsley, R. S., \& Schneller, M. I. (2009). Information uncertainty and auditor reputation. Journal of Banking \& Finance, 33(2), 183-192. https://doi.org/10.1016/j.jbankfin.2008.07.011

Brown, K. F., \& Dang, L. (2011). Consequences of auditor reputation loss for client firms: deterioration of financial reporting quality after the Andersen collapse. International Journal of Business Innovation and Research, 5(3), 318-331.

Cano-Rodríguez, M., Sánchez-Alegría, S., \& Arenas-Torres, P. (2016). The influence of auditor's opinion and auditor's reputation on the cost of debt: evidence from private Spanish firmsLa influencia de la opinión de auditorãa y la reputación del auditor en el coste de la deuda: evidencia en las empresas españolas no cotizadas. Spanish Journal of Finance and Accounting/Revista Española de Financiación y Contabilidad, 45(1), 32-62.

Cho, S., \& Kim, Y. C. (2012). Corporate social responsibility (CSR) as a halo effect in issue management: public response to negative news about pro-social local private companies. Asian Journal of Communication, 22(4), 372385.

Christensen, L. B. (2004). Experimental methodology. Allyn \& Bacon.

Cohen, J., Ding, Y., Lesage, C., \& Stolowy, H. (2017). Media bias and the persistence of the expectation gap: An analysis of press articles on corporate fraud. Journal of Business Ethics, 144(3), 637-659.

Coombs, W. T., \& Holladay, S. J. (2006). Halo or reputational capital: Reputation and crisis management. Journal of Communication Management, 10(2), 123-137.

Craswell, A. T., Francis, J. R., \& Taylor, S. L. (1995). Auditor brand name reputations and industry specializations. Journal of accounting and economics, 20(3), 297-322. https://doi.org/10.1016/01654101(95)00403-3

Doney, P. M., \& Cannon, J. P. (1997). An examination of the nature of trust in buyer-seller relationships. Journal of marketing, 61(2), 35-51.

Ehavior, B., \& Pavlou, P. A. (2002). Evidence of the effect of trust building technology in electronic markets: price premiums and buyer. MIS Quartely, 26(3), 243-268.

Field, A. (2009). Discovering statistics using SPSS:(and sex and drugs and rock'n'roll). Sage.

Frooman, J. (1999). Stakeholder influence strategies. Academy of management review, 24(2), 191-205.

Gagne, R. M. (1984). Learning outcomes and their effects: Useful categories of human performance. American psychologist, 39(4), 377.

Godbey, J. M., \& Mahar, J. W. (2005). IMPLIED VOLATILITIES AND AUDITOR REPUTATION: THE ANDERSEN CASE', Research in Finance (Research in Finance, Volume 21).

Gramling, A. A., Schatzberg, J. W., \& Wallace, W. A. (1996). The role of undergraduate auditing coursework in reducing the expectations gap. Issues in Accounting Education, 11(1), 131.

Herbig, P., Milewicz, J., \& Golden, J. (1994). A model of reputation building and destruction. Journal of Business Research, 31(1), 23-31. https://doi.org/10.1016/0148-2963(94)90042-6

Hillison, W., \& Pacini, C. (2004). Auditor reputation and the insurance hypothesis: The information content of disclosures of financial distress of a major accounting firm. Journal of Managerial Issues, 65-86.

Hogarth, R. M., \& Einhorn, H. J. (1992). Order effects in belief updating: The belief-adjustment model. Cognitive psychology, 24(1), 1-55. https://doi.org/10.1016/0010-0285(92)90002-J

Kanagaretnam, K., Krishnan, G. V., \& Lobo, G. J. (2009). Is the market valuation of banks' loan loss provision conditional on auditor reputation?. Journal of Banking \& Finance, 33(6), 1039-1047. https://doi.org/10.1016/j.jbankfin.2008.10.013

Krishnamurthy, S., Zhou, J., \& Zhou, N. (2006). Auditor reputation, auditor independence, and the stock-market impact of Andersen's indictment on its client firms. Contemporary Accounting Research, 23(2), 465-490.

Lennox, C. S. (1999). Audit quality and auditor size: An evaluation of reputation and deep pockets hypotheses. Journal of Business Finance \& Accounting, 26(7-8), 779-805.

Leuthesser, L., Kohli, C. S., \& Harich, K. R. (1995). Brand equity: the halo effect measure. European journal of marketing. 
Magnis, C., \& Iatridis, G. E. (2017). The relation between auditor reputation, earnings and capital management in the banking sector: An international investigation. Research in International Business and Finance, 39, 338-357. https://doi.org/10.1016/j.ribaf.2016.09.006

Mayhew, B. W. (2001). Auditor reputation building. Journal of Accounting Research, 39(3), 599-617.

McGeoch, J. A. (1933). The psychology of human learning: a bibliography. Psychological Bulletin, $30(1), 1$.

McKnight, D. H., Choudhury, V., \& Kacmar, C. (2002). The impact of initial consumer trust on intentions to transact with a web site: a trust building model. The journal of strategic information systems, 11(3-4), 297-323. https://doi.org/10.1016/S0963-8687(02)00020-3

Monroe, G. S., \& Woodliff, D. R. (1993). The effect of education on the audit expectation gap. Accounting \& Finance, 33(1), 61-78.

Morgan, R., \& Hunt, S. (1994). The commitment-trust theory of marketing relationships. Journal of Marketing, 58(3), 20-38.

Nahartyo, E., \& Utami, I. (2014). Altering Rationality: The Impact of Group Support Systems and Style of Leadership. Journal of Applied Management Accounting Research, 12(2).

Nisbett, R. E., \& Wilson, T. D. (1977). The halo effect: evidence for unconscious alteration of judgments. Journal of personality and social psychology, 35(4), 250.

Park, C. K., Xu, Z. Z., Liu, T., Lü, N., Serhan, C. N., \& Ji, R. R. (2011). Resolvin D2 is a potent endogenous inhibitor for transient receptor potential subtype V1/A1, inflammatory pain, and spinal cord synaptic plasticity in mice: distinct roles of resolvin D1, D2, and E1. Journal of Neuroscience, 31(50), 18433-18438.

Pierce, B. P., \& Kilcommins, M. (1997). The impact of undergraduate auditing modules on the audit expectations gap. Irish Accounting Review, 4(2), 89-118.

Putra, G. S. A., \& Dwirandra, A. A. N. B. (2019). The effect of auditor experience, type of personality and fraud auditing training on auditors ability in fraud detecting with professional skepticism as a mediation variable. International research journal of management, IT and social sciences, 6(2), 31-43.

Rifa'i, A., \& Anni, C. T. (2012). Psikologi Pendidikan Smarang: Pusat Pengembangan MKU. MKDK-LP3 UniversitasNegeri Semarang.

Rodgers, W., Guiral, A., \& Gonzalo, J. A. (2019). Trusting/Distrusting Auditors' Opinions. Sustainability, 11 (6), 1666.

Shadish, W. R., Cook, T. D., \& Campbell, D. T. (2002). Experimental and quasi-experimental designs for generalized causal inference/William R. Shedish, Thomas D. Cook, Donald T. Campbell. Boston: Houghton Mifflin,.

Skinner, B. F. (1958). Teaching machines. Science, 128(3330), 969-977.

Tedeschi, J. T. (Ed.). (2013). Impression management theory and social psychological research. Academic Press.

Thorndike, E. L. (1920). A constant error in psychological ratings. Journal of applied psychology, 4(1), 25-29.

Weber, J., Willenborg, M., \& Zhang, J. (2008). Does auditor reputation matter? The case of KPMG Germany and ComROAD AG. Journal of Accounting Research, 46(4), 941-972.

Rama, R. S. ., T, S., Saraswati, E. ., \& Rahman, A. F. . (2020). Debiasing halo effect: auditor reputation and the role of auditing learning on financial statements user trust. International Research Journal of Management, IT and Social Sciences, 7(6), 33-41. https://doi.org/10.21744/irjmis.v7n6.1006 